\title{
TAXONOMIC NOVELTIES IN SOUTHERN BRAZILIAN AMARYLLIDACEAE - IV: HIPPEASTRUM CORREIENSE (BURY) WORSLEY, THE CORRECT NAME OF THE FAMOUS H. MORELIANUM LEM.; AND H. VERDIANUM, A NEW SPECIES FROM SANTA CATARINA ${ }^{1}$
}

\author{
HENRIQUE MALLMANN BÜNEKER ${ }^{2}$ REGIS EDUARDO BASTIAN ${ }^{3}$
}

\begin{abstract}
In this article, Hippeastrum verdianum, a new species of Amaryllidaceae (Amaryllidoideae, Hippeastreae), which occurs in rocky cliffs in Santa Catarina (Brazil), is described and illustrated. Data are provided on their habitat, ecology and geographical distribution. The new species shows morphological affinity with $H$. correiense and $H$. papilio. In order to establish a consistent argumentative basis for the description of the new species, we clarify the taxonomic identity of $H$. correiense, proposing lectotypes for it as well as other binomials that we consider as synonyms.

Keywords: Taxonomy, Monocot, Amaryllidoideae, Hippeastreae, Hippeastrinae, Hippeastrum subgen. Omphalissa
\end{abstract}

\section{RESUMO}

[Novidades taxonômicas em Amaryllidaceae sul-brasileiras - IV: Hippeastrum correiense (Bury) Worsley, o nome correto do famoso H. morelianum Lem.; e H. verdianum, uma nova espécie para Santa Catarina].

É descrito e ilustrado Hippeastrum verdianum, uma nova espécie de Amaryllidaceae (Amaryllidoideae, Hippeastreae) que ocorre em escarpas rochosas de Santa Catarina (Brasil). São fornecidos dados sobre seu hábitat, ecologia e distribuição geográfica. A nova espécie apresenta afinidade morfológica com $H$. correiense e H. papilio. Para estabelecer uma base argumentativa consistente para descrição da nova espécie esclarecemos a identidade taxonômica de $H$. correiense, propondo lectótipos para ele e outros binômios que consideramos como seus sinónimos.

Palavras-chave: Taxonomia, Monocotiledônea, Amaryllidoideae, Hippeastreae, Hippeastrinae, Hippeastrum subgen. Omphalissa

\section{INTRODUCTION}

There are currently 22 species of Amaryllidaceae, subfamily Amaryllidoideae occurring naturally in the state of Santa Catarina (Brazil). They are contained in the genera: Crinum Linnaeus (1753: 291) (1 sp.), Eithea Ravenna (2002: 2) (1 sp.), Eusarcops Rafinesque (1836: 11) (1 sp.), Habranthus Herbert (1824: t. 2464) (3 spp.), Hippeastrum Herbert (1821: 31) (12 spp.) and Zephyranthes

1 Recebido em 03-IX-2018 e aceito para publicação em 03-X-2018.

2 Técnico em Paisagismo e acadêmico do curso de Engenharia Florestal, Universidade Federal de Santa Maria. henriquemallmannbuneker@googlemail.com

3 Biólogo do Centro de Reprodução de Espécies Raras do Brasil (CRER Brasil). crerbrasil@ hotmail.com
Herbert (1821: 36) (5 spp.) (Flora do Brasil 2020, under construction; Büneker \& Bastian, 2016; 2018).

The first described species of Amaryllidaceae, Amaryllidoideae, from material reliably coming from the state of Santa Catarina (Brazil) is Griffinia blumenavia Koch \& Bouché ex Carrière (1867: 32) (currently Eithea blumenavia (Koch \& Bouché ex Carrière) Ravenna (2002: 4)). This species was described by Carrière (1867) based on a specimen grown in the Berlin Botanical Garden, from the "island of Santa Catarina" ${ }^{4}$ and sent by Dr. H.

\footnotetext{
${ }^{4}$ The island of Santa Catarina is part of the municipality of Florianopolis, in the state of Santa Catarina, Brazil.
} 
Blumenau ${ }^{5}$, also in the nineteenth century, Zephyranthes taubertiana Harms (1895:81) (synonym of Habranthus robustus Herbert ex Sweet (1938: t. 14), which had recently been introduced into the living collection of the Berlin Botanical Garden, from bulbs sent from Blumenau by F. Müller ${ }^{6}$ ). After a lapse of 63 years, already in the second half of the twentieth century, Amaryllis santacatarina Traub (1958: 32) (currently Hippeastrum sanctaecatharinae ${ }^{7}$ (Traub) Dutilh (in Meerow et al. 1997: 18)), whose typi material came from collections of the expedition carried out in 1956 by L.B. Smith $^{8}$ and priest R. Reitz ${ }^{9}$ in the interior of the state of Santa Catarina (material deposited in the herbariums MO and US). Afterwards several species, whose original specimens are coming from this Brazilian state, came to light through the studies conducted by P.F. Ravenna ${ }^{10}$ (Zephyranthes flavissima Ravenna (1967: 28), Amaryllis papilio Ravenna (1970: 83) (currently Hippeastrum papilio (Ravenna) Van Scheepen

${ }^{5}$ Hermann Bruno Otto Blumenau (1819-1899) was a German philosopher, administrator and chemist and the founder of the municipality of Blumenau, in the state of Santa Catarina (Brazil).

${ }^{6}$ Johann Friedrich Theodor Müller (1822-1897) was a naturalist, botanist, zoologist and professor of mathematics and natural sciences, German, appointed in 1877 naturalist traveller of the National Museum by Dom Pedro II. He settled in the colony of Blumenau (Santa Catarina) in 1852. He had 248 published articles and was a consistent correspondent of C. Darwin. He is the author of the book Für Darwin (1864), whose edition in English, facts and arguments for Darwin (1869) was organized by C. Darwin himself (Fontes \& Hagen, 2009).

7 "sanctaecatharinae" is the correct latinization, corrected by Büneker \& Bastian (2017) of the original erroneous epithet "santacatarina".

${ }^{8}$ Lyman Bradford Smith (1904-1997) was an American botanist and the Emeritus Curator of the Department of Botany, Museum of Natural History, Smithsonian Institution. Renowned authority on the Bromeliaceae, Velloziaceae, Xyridaceae, and Begoniaceae, co-ordinator and major contributor to the Flora of Santa Catarina. $\mathrm{He}$ had an extraordinarily productive career both as a taxonomist and plant collector, having published over 1500 new species in more than 450 papers (Smith, 1997).

${ }^{9}$ Raulino Reitz (1919-1990) was a catholic priest, botanist and Brazilian historian. He founded in 1942, the Herbarium Barbosa Rodrigues (in Itajaí, Santa Catarina, (in Meerow et al. (1837: 139)), Amaryllis hemographes Ravenna (1982: 46) (currently Hippeastrum hemographes (Ravenna) Dutilh (in Meerow et al. 1997: 17)) Herbert (1837: 139)) and Zephyranthes lagesiana Ravenna (2001: 40)), these being the last taxonomic novelties described for Santa Catarina before our Zephyranthes comunelloi Bastian \& Büneker (2018: 2).

Through our studies on the Amaryllidaceae of southern Brazil, we were able to locate a new species for the state of Santa Catarina. Continuing the series of articles on taxonomic novelties for the Southern Brazilian Amaryllidaceae (Büneker \& Bastian, 2017; 2018), we propose in this work a new species for the genus Hippeastrum. The new species is similar to $H$. correiense. Then, in order to properly compare the two, it is necessary to clarify what the identity of $H$. correiense. Thus, we are here proposing lectotypifications and synonyms of several names in him, including the well known in horticulture $H$. morelianum.

\section{MATERIAL AND METHODS}

Specimens were collected for laboratory study, cultivation and herborization. The living specimens were included in the living collection of CRER Brasil (Centro de Reprodução de Espécies Raras do Brasil, Rio Grande do Sul, Brazil). The morphological variation of this new species was observed in habitat, in cultivated

Brazil), was editor-in-chief of the scientific journal Sellowia and organizer of Flora Ilustrada Catarinense, for which he contributed with 40 monographs. He carried out extensive collections of botanical specimens in the state of Santa Catarina, surpassing 30,000 numbers. He described 327 species and five new genera for science (Marchiori, 2013). He was a renowned specialist of Bromeliaceae and director of the Botanical Garden of Rio de Janeiro (1971-1975), where he left as a legacy the until now renowned ecological bromeliarium (Reitz, 1975).

${ }^{10}$ Pedro Félix Ravenna (1938-) is a Chilean botanist taxonomist, specialist in Amaryllidaceae and South American Iridaceae, described more than 350 new species for science. 
and in herbaria specimens. The terminology used in the description follows Büneker et al. (2016). The data on related species was obtained in the original descriptions and herbaria collections. The collections of the following herbaria were consulted: HAS, HDCF, ICN, MBM, PACA, R, RB; digital collections of B, ESA, K, MO, NY, P, US, UEC and VIC; acronyms according Thiers (2013). The photographs were taken from plants in natural habitat and in cultivation, and the drawings were based on living material.

\section{RESULTS \& DISCUSSION}

The subgenera of Hippeastrum are not being effectively used today probably because there is evidence that suggests that some of them are artificial. However, they can facilitate taxonomy and identification, since the genus has a relatively large number of species. Hippeastrum subgen. Omphalissa (Salisbury) Baker, whose species type is H. aulicum (Ker Gawler) Herbert, appears to be natural due to a series of morphological evidences, such as the two flowered inflorescence (rarely 3-4-flowered) and its strongly zygomorphic flowers, with reduced hypanthium, and with an strongly declined-ascending androecium and gynoecium. This subgenus shows relevant diversity on the Atlantic coast of South America, especially in Brazil. In Brazil, we can recognize a series of species of this subgenus; these form complexes of closely related species, such as: the $H$. psittacinum complex (e.g. include: $H$. glaucescens (Martius ex Schultes \& Schultes f.) Herbert, H. psittacinum (Ker Gawler) Herbert, H. iguazuanum (Ravenna) Dudley \& Williams, $H$. rubropictum (Ravenna) Meerow, $H$. aviflorum (Ravenna) Dutilh, H. caiaponicum (Ravenna) Dutilh, H. curitibanum (Ravenna) Dutilh, $H$. hemographes (Ravenna) Dutilh, $H$. illustre (Velloso) Dutilh, H. kromeri (Worsley) Meerow, $H$. maracasum (Traub) Moore, $H$. decoratum Lemaire, $H$. restingense (Ravenna) Büneker \& Bastian comb. nov. (Basionym: Amaryllis restingensis Ravenna (1969: 70)), $H$. teyucuarense (Ravenna) Van Scheepen and $H$. paradisiacum (Ravenna) Meerow); the $H$. aulicum complex (e.g. include: $H$. aulicum, $H$. calyptratum (Ker Gawler) Herbert, $H$. marumbiense (Ravenna) Van Scheepen and $H$. platypetalum (Lindley) Büneker \& Bastian comb. nov. (Basionym: Amaryllis aulica var. platypetala Lindley (1827: t. 1038)); and the $H$. correiense complex (e.g. include: $H$. correiense (Bury) Worsley, H. papilio (Ravenna) Van Scheepen and $H$. verdianum sp. nov.).

The new species that is described in this work belongs to the $H$. correiense complex, and its prevalent resemblance is with $H$. correiense. We noticed that $H$. correiense, despite being a very old name, did not present a clear identity. Below, we present a nomenclature revision with the objective of bringing to light the correct identity of this binomial. To support this, a series of lectotypes is necessary. During our taxonomic nomenclature revision we noticed that $H$. correiense is a species of relatively wide occurrence, and it is very morphologically variable, being that several of the extremes of its morphological variation were described as species; thus, leading us to propose a great amount of synonymy. From the understanding of the intraspecific morphological variations of $H$. correiense, we were able to notice their differences in relation to $H$. verdianum, which we here describe.

\section{TAXONOMIC-NOMENCLAT URAL TREATMENT}

1. Hippeastrum correiense (Bury) Worsley, The Gardeners' Chronicle \& Agricultural Gazette, ser. 3, v. 85, p. 377, 1929, (Figs. 1-5).

Basionym: Amaryllis correiensis Bury, Selection of Hexandrian Plants, Belonging to the Natural Order Amaryllidae and Liliaceae, t. 9, 1831[1834].

Type: Lectotype (designated here): illustration from Selection of Hexandrian Plants, Belonging to the Natural Order Amaryllidae and Liliaceae, t. 9, 1831[1834], (Fig. 1). 
= Amaryllis aulica var. glaucophylla Hooker, Curtis's Botanical Magazine, v. 57, t. 2983, 1830 = Hippeastrum aulicum var. glaucophyllum (Hooker) Herbert, Amaryllidaceae, p. 136, 1837, syn. nov.

Type: Lectotype (designated here): illustration from Curtis's Botanical Magazine, v. 57, t. 2983, 1830, (Fig. 2).

= Hippeastrum organense Herbert, Curtis's Botanical Magazine, v. 67, t. 3803, $1840=$ Amaryllis organensis (Herbert) Traub \& Uphof, Herbertia, v. 5, p. 129, 1938, syn. nov.

Type: Lectotype (designated here): illustration from Curtis's Botanical Magazine, v. 57, t. 2983, 1830, (Fig. 2).

= Hippeastrum organense var. compressum Herbert, Edwards's Botanical Register, v. 28, (Miscellaneous Matter of the Botanical Register 1842), p. 39, $1842=$ Amaryllis organensis var. compressa (Herbert) Traub, Plant Life, v. 7, p. 35, 1951, syn. nov.

Type: unknown

= Hippeastrum morelianum Lemaire, L'Horticulteur Universel, v. 4, p. 37, $1843=$ Amaryllis moreliana (Lemaire) Traub, Herbertia v. 13, p. 102, 1948, syn. nov.

Type: Lectotype (designated here): illustration from L'Horticulteur Universel, v. 4, p. (36-)tabula(-37), 1845, (Fig. 3).

= Hippeastrum heuserianum Karsten, Florae Columbiae, v. 2, p. 3, t. 102, $1862=$ Amaryllis heuseriana (Karsten) Ravenna, Plant Life, v. 30, p. 63, 1974, syn. nov.

Type: Lectotype (designated here): illustration from Florae Columbiae, v. 2, t. 102, 1862, (Fig. 4).

= Hippeastrum damazianum Beauverd, Bulletin de L'Herbier Boissier, ser. 2, v. 6, p. 585, 1906 = Amaryllis damaziana (Beauverd) Traub \& Uphof, Herbertia, v. 5, p. 127, 1938, syn. nov.

Type: BRAZIL. Minas Gerais: Sur les roches, plateau de 1'Itaculumi, October 1904, L. Damazio 1481 (Holotype G!; Isotype RB!, Fig. 5).
= Amaryllis lavrensis Ravenna, Onira, v. 9, p. 12, 2003, syn. nov.

Type: BRAZIL. Minas Gerais: Lavras, em campo rupestre, 10 December 1980, H.F. Leitão Filho 11944, G. Shepherd, F.R. Martins et al. (Holotype UEC; Isotypes MBM!, VIC!).

= Hippeastrum atibaya Piratelli, Revista Brasileira de Biologia, v. 57, p. 261, 1997, nom. nud.

Nomenclatural observations: Presently, there seems to be a consensus about the identity of the species here treated as $H$. correiense, which for some decades has been identified as H. morelianum. The latter has been widely used to identify this species, especially in the horticultural environment where it is widely disseminated, since it is one of the main species used in hybridization and genetic improvement processes. We could not locate the origin of this error, but is fully understandable that it has been propagated by the absence of typifications and nomenclature revisions of Hippeastrum. There is a common sense about the identity of some names; however, it is largely misleading and disconnected from the true identity of the binomials, having no commitment with the International Code of Nomenclature for Algae, Fungi, and Plants (Turland et al., 2018). These identification errors have been routinely propagated in scientific floristic studies, and are cause for confusion in taxonomy. All of this has generated a situation of generalized taxonomicnomenclature chaos in this group. From this, we realized that there would be no way to propose a new species related to $H$. correiense without first carrying out a taxonomic-nomenclature revision in order to clarify its identity.

The excellent color illustration provided along with the description of $H$. correiense does not raise doubt about its identity (Fig. 1). The description of the species, as well as its illustration, was based on a specimen coming from Serra dos Orgãos and sent to England, first blossoming on January 17, 1830. We did not 


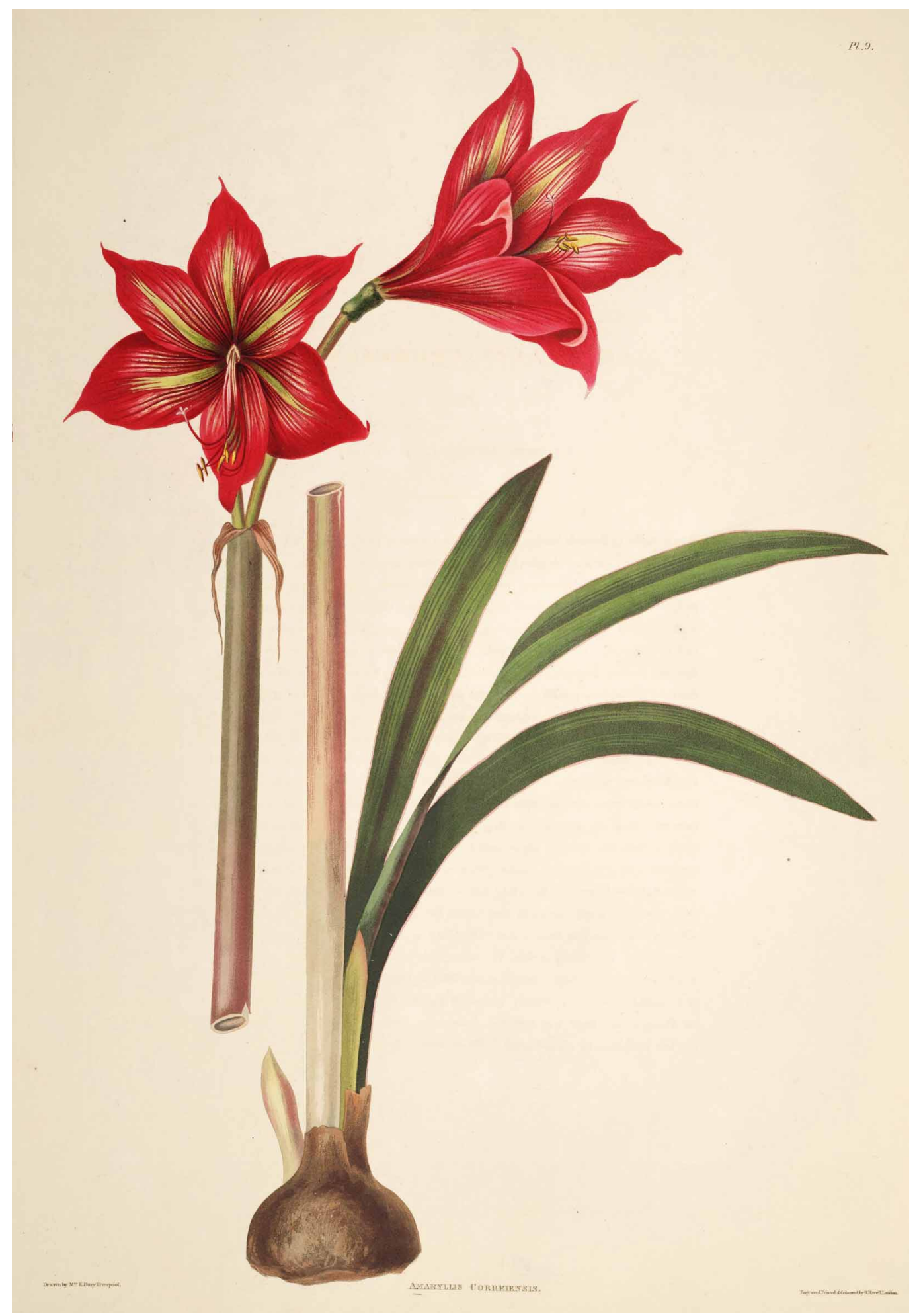

FIGURE 1 - Lectotype of Amaryllis correiensis Bury. Illustration extracted from Selection of Hexandrian Plants, Belonging to the Natural Order Amaryllidae and Liliaceae, t. 9, 1831[1834]. 


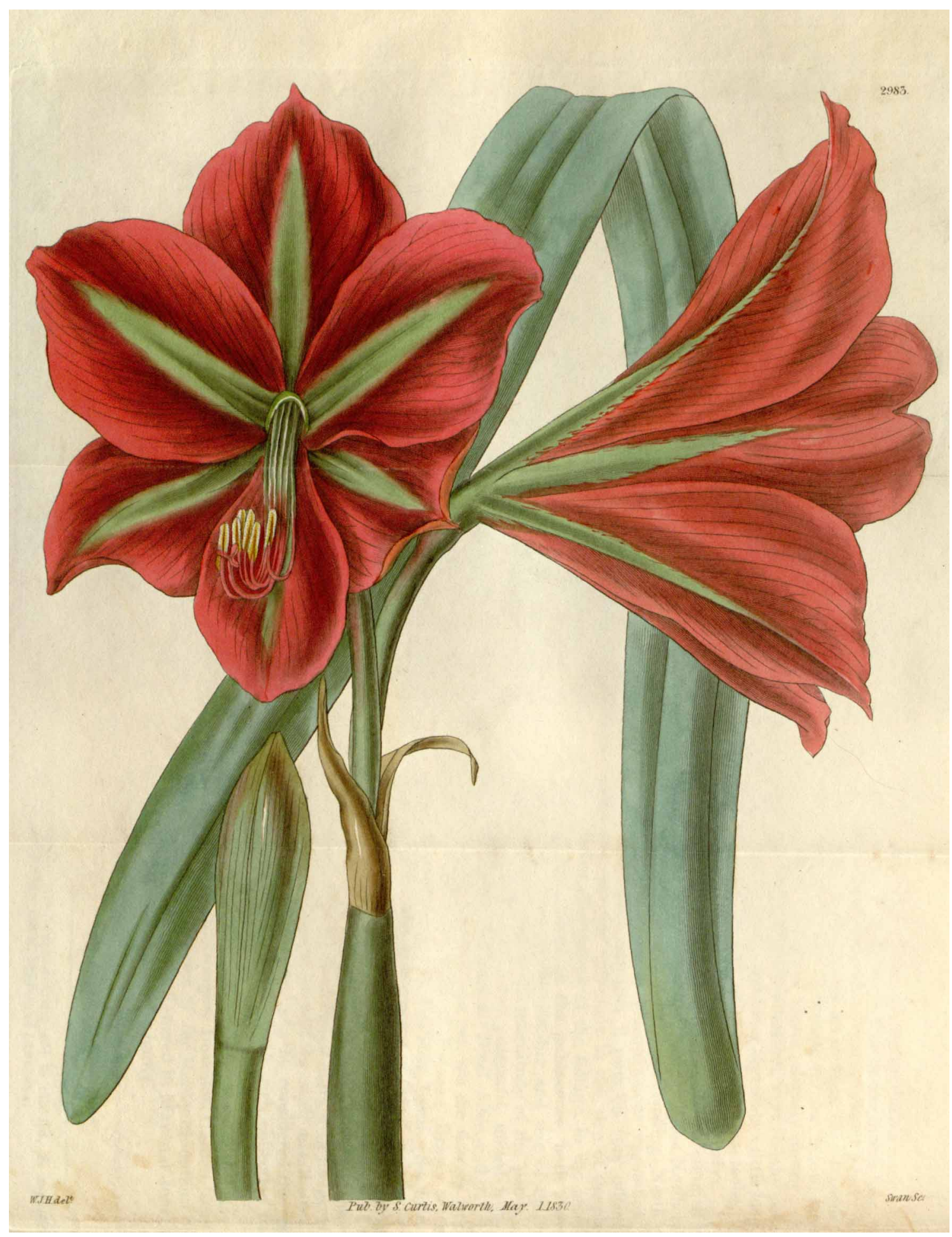

FIGURE 2 - Lectotype of Amaryllis aulica var. glaucophylla Hooker and Hippeastrum organense Herbert. Illustration extracted from Curtis's Botanical Magazine, v. 57, t. 2983, 1830 (Image credits: Missouri Botanical Garden, Peter H. Raven Library). 


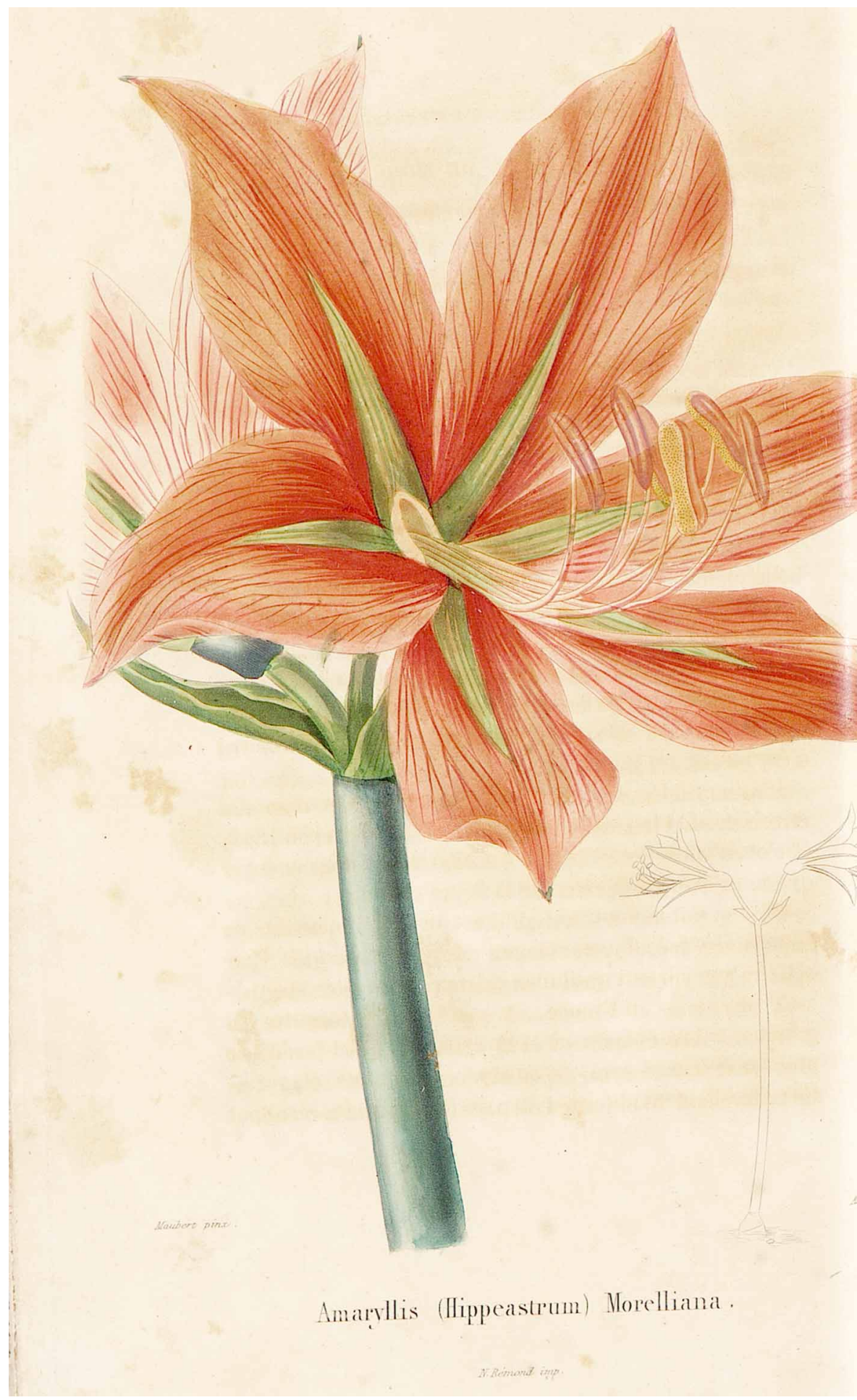

FIGURE 3 - Lectotype of Hippeastrum morelianum Lemaire. Illustration extracted from L'Horticulteur Universel, v. 4 , p. (36-)tabula(-37), 1845 (Image credits: Hortalia, Biliothèque de la Société nationale d'horticulture de France). 


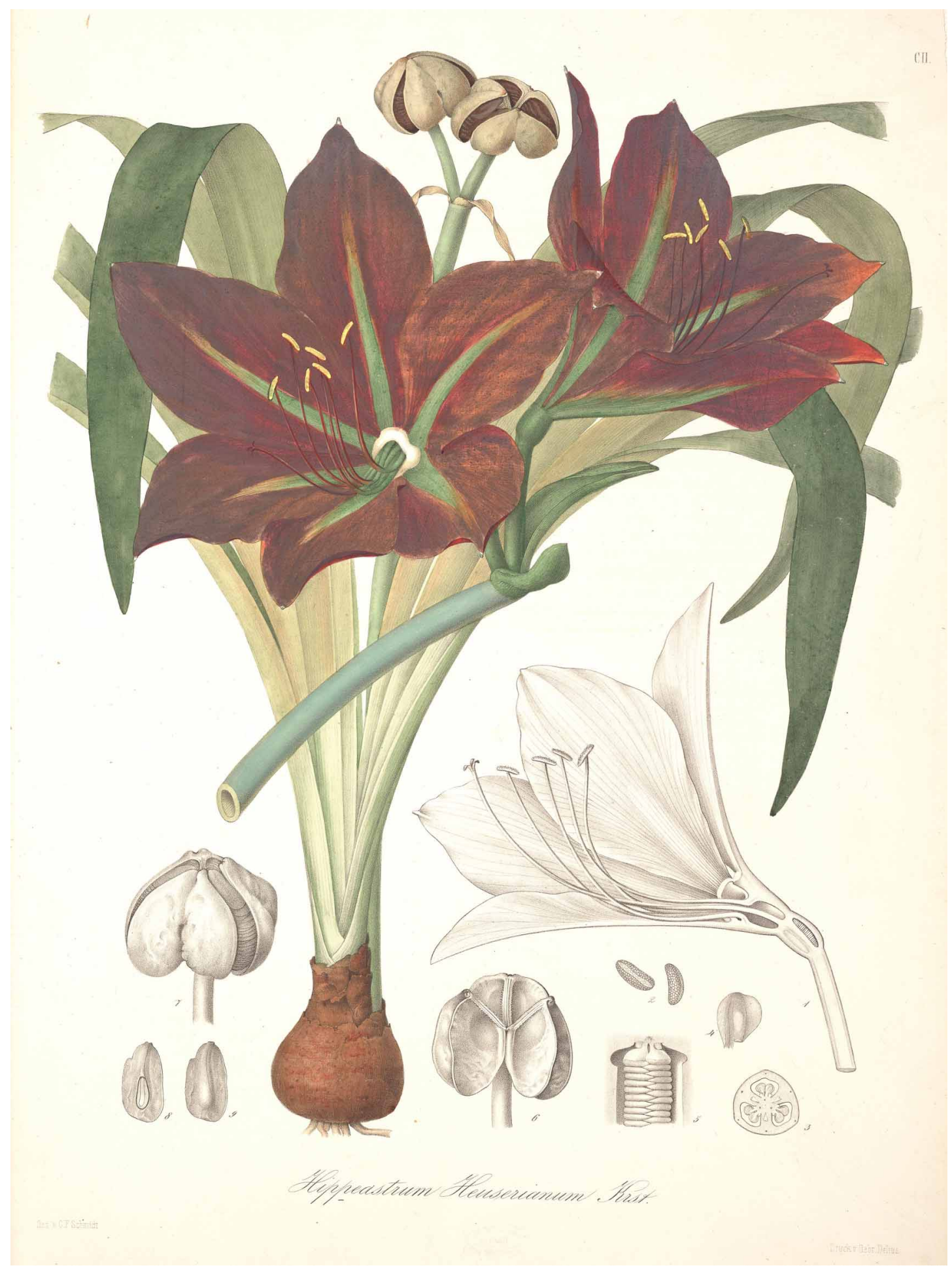

FIGURE 4 - Lectotype of Hippeastrum heuserianum Karsten. Illustration extracted from Florae Columbiae, v. 2, t. 102 , 1862 (Image credits: Missouri Botanical Garden, Peter H. Raven Library). 


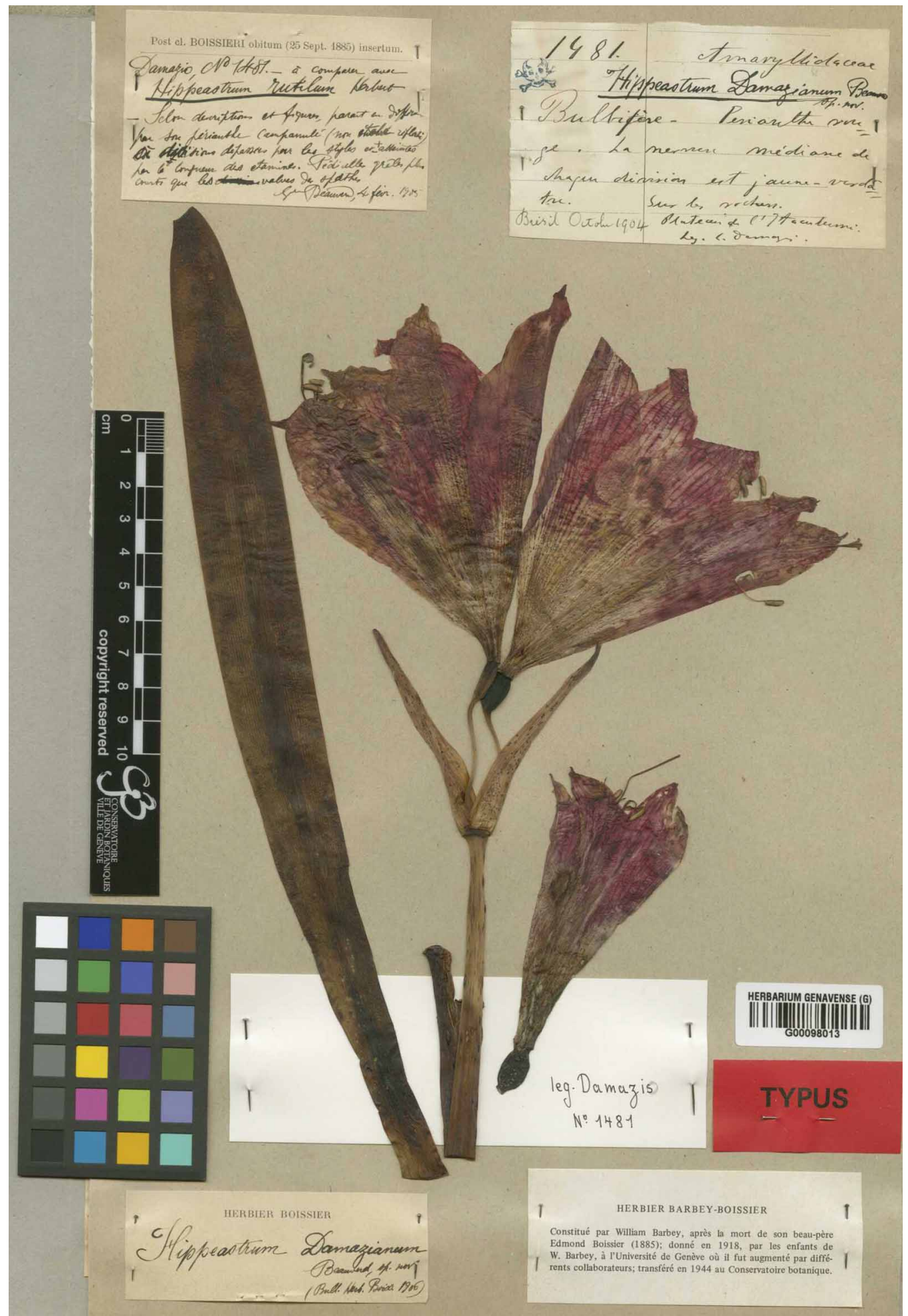

FIGURE 5 - Holotype (L. Damazio 1481) of Hippeastrum damazianum Beauverd (Image credits: G Herbarium, Barcode : G00098013). 
locate any type material deposited in the herbarium, and therefore, here we indicate as lectotype its original illustration. From this lectotypification, which clarifies the identity of the binomial $H$. correiense, we were able to verify that it has priority over a series of other names, including the well-known $H$. morelianum (Fig. 3). As informed in their original works, $H$. organense and $H$. aulicum var. glaucophyllum also come from Serra dos Órgãos. Herbert (1938), in describing Amaryllis organensis, clarifies that he was giving this name to the taxa formerly called $H$. aulicum var. glaucophyllum of Hooker (1830), and relied on Hooker's material to describe it as a species. Thus we indicate as lectotype (Fig. 2), for both taxa, the same illustration making them homotypic. In a later work Herbert (1837) considers this taxon as $H$. aulicum var. glaucophyllum and does not present treatment to $H$. organense.

Karsten (1862) described H. heuserianum, providing an excellent illustration here indicated as lectotype (Fig. 4). Overall, the morphological descriptions of Hippeastrum from the nineteencentury do not include the paraperigone, which is important to differentiate some species; not even the illustrations show their details. The original illustration of $H$. heuserianum presents a flower cut that is not conclusive wit regards to the paraperigone morphology. In the illustration it is possible to verify that it is present, however there are no details to verify its type. The illustrated leaves are very similar to those of the $H$. correiense lectotype: slightly glaucous, with acute apex, being an uncommon variation in a natural environment. However, its cultivation in humid greenhouses and with poorer isolation is probably the cause for this morphology. This can be observed in the illustrations of plants grown in Europe.

Piratelli (1997) studied the feeding behavior of hummingbirds in two species of Hippeastrum, one of which was treated as $H$. atibaya. According to Flora do Brasil 2020 (2018), this name would have originated in an article by
Blossfeld (1979), which described Amaryllis atibaya, and Piratelli (1997) would have altered it to Hippeastrum. We found, however, that Blossfeld (1979) did not mention in any part of his text the binomial attributed to him by authorship. The theme of the article by Blossfeld (1979) is the identity of the species of a Hippeastrum population that occurs in a place called "pedra grande" in Atibaia (São Paulo, Brazil). This species in treated by him as "Amaryllis sp. "Atibaya"”. In this article we verify that Blossfeld (1979) does not author the binomials Amaryllis atibaya, which has never been formally published, and Piratelli (1997) is the author of a nomen nudum (H. atibaya). We attributed the identity of this species to $H$. correiense.

Distribution, Habitat and Ecology: The species is heliophyte and saxicolous, rarely found in a shady environment. It occurs in relatively high altitudes, in inselbergs generally surrounded by Atlantic rainforest, presenting populations disjointed by the fragmented environment it occupies. H. correiense is endemic of Brazil, occurring in the mountainous region of the states of Minas Gerais, Rio de Janeiro and São Paulo. It shows significant populations in the Itatiaia National Park and in the National Park of Serra dos Órgãos, both in the state of Rio de Janeiro. Its southernmost populations are in the region of Atibaia, in the northeast of the state of São Paulo. Ravenna (1982) reports the occurrence of Amaryllis moreliana (now synonym of $H$. correiense) in the Quiriri mountain range, located in the northeast of the state of Santa Catarina, raising the possibility of the species occurring in the state of Paraná as well. This author relied on two specimens collected by Reitz \& Klein 9815 and 5235 (HBR) to support his argument. We analyzed a Reitz \& Klein 5235 digitalized duplicate deposited in the US herbarium, and verified that it is $H$. aff. glaucescens. We could not locate any other population of $H$. correiense further south of São Paulo. 
Taxonomic observations: $H$. correiense shows wide floral morphological variation, mainly in coloration, shape and width of tepals. This morphological variation can be observed among individuals within populations. Individuals that present the extremes of these variations, analyzed outside the population context, may lead to the idea of being distinct species, and this was probably what led to the description of several names that we consider to be synonyms. If we accept these binomials with morphological basis as distinct species, we should consider that two or even three species could occur in the same habitat. Clearly, it would be an artificial (purely typological) concept to these species, and disregarding the existence of morphologically intermediate individuals. Thus, in an accurate analysis, we observe that this morphological variation is continuous, not being distinct species.

The lectotypes of $H$. morelianum (Fig. 3), $H$. heuserianum (Fig. 4) and H. organense (Fig. 2) show perigone with very similar coloration and shape, relatively atypical for the species, since the majority of the populations present, besides the coloration of red tepals with a green stripe in the central region, greenish-white in the base. However, this color variation is routinely observed within typical populations, and is not of taxonomic relevance.

$H$. correiense presents a saxicolous habit, similar to that of $H$. papilio and $H$. verdianum, although the latter two occur generally in an environment with lower solar incidence, and $H$. correiense is heliophyte. The populations of this species occupy a series of mountainous formations that accompany the continental coastline of Southern Brazil, showing that appears to be a geographical cohesion what suggests the vicariance of a common ancestor. The three species that compose the H. correiense complex present a great similarity in the form and ornamentation of the tepals, but can be differentiated by the paraperigone and staining of the tepals and maculae that accompany the nervures.
Specimens examined: Minas Gerais: s.l., 1841, G. Gardner 5210 (K); Caldas, Pedra Branca, 10 August 2000, J.H.A. Dutilh s.n. (UEC 170599); Extrema, Serra do Lopo, coletada na pedra das flores, 12-13 May 2005, L.S. Kinoshita s.n. et al. (UEC 155083); 25 September 2009, J. Semir s.n. (UEC 81476); Itamonte, Serra da Mantiqueira, afloramento rochoso no alto do morro, 8 October 1982, G. Hatschbach 45553 (MBM); Ouro Preto, Parque Estadual do Itacolomi, final da trilha do Baú a direita, July 2000, A.N. Caiafa \& C.C. Paula s.n. (VIC 25126); Camarinhas, formação arbustiva herbácea, rupestre, 14 October 1987, M. Peron 407 (RB); Caeté, Serra da Piedade, trilha abaixo do restaurante, 19 May 1993, J.A. Lombardi \& F.R.N. Toledo 251 (UEC); 16 June 1933, M. Barreto 614 (US); Carrancas, Serra de Bicas, mata a cerca de 1200, de altitude, 12 November 1998, A.O. Simões 508 et al. (UEC); 22 September 1998, A.O. Simões 325 et al. (UEC); alto da Serra do Moleque, afloramento rochoso a cerca de $1400 \mathrm{~m}$ de altitude, 2 October 1999, A.O. Simões 884 et al. (UEC); 5 November 1999, A.O. Simões 972 et al. (UEC); Camanducaia, Monte Verde, afloramento da Pedra do Selado, 28 June 2001, L.D. Meireles 349 (UEC); Pico do Selado, 2 July 2001, J.H.A. Dutilh s.n. (UEC 170480); Moeda, Serra da Moeda, estrada que liga a BR040 a Moeda, 12 October 1992, V.C. Souza 2055 et al. (ESA); Belo Horizonte, Pico da Piedade, 10 June 1940, M.B. Foster 614 (US); Rio de Janeiro: s.l., 18161821, A. de Saint-Hilaire s.n. (P 02055366); Orgãos, 21 January 1887, A. Glaziou 16386 (P); Itatiaia, Parque Naconal do Itatiaia, próximo ao abrigo Rebolças, 12 December 2007, R.S. Oliveira \& R.P. Camargo 111 (UEC); 12 October 1987, M.C. Schmitz s.n. (ESA 3391); 26 July 1999, J.H.A. Dutilh s.n. (UEC 170542); planalto, 2400m, 25 July 1996, D.R. Hunt 6434 (UB); Agulhas Negras, 30 May 1969, D. Sucre 5136 \& T. Plowmann (RB); estrada para o Pico das Agulhas Negras, 13 September 1987, R. Guedes 2435 (RB); próximo a pedra da tartaruga, 8 November 2017, M. Nadruz 3261 (RB); Nova 
Friburgo, 25 August 1999, J.H.A. Dutilh s.n. (UEC 170479); Teresópolis, Parque Estadual dos Três Picos. Seio de Mulher de Pedra, próximo ao cume, 17 January 2015, C. Baez 212 (RB); São Paulo: Atibaia, pedra grande, 22 August 1985, P.C. Hutchison 8940 (RB); Parque Municipal da Grota Funda, s.d., L.C. Bernacci 28419 et al. (UEC); s.d., L.C. Bernacci 28417 et al. (UEC);

2. Hippeastrum verdianum Büneker \& R. Bastian, sp. nov., (Figs. 6A-C, 7A-D).

Species morphologice proxima Hippeastro correiensi, et secunde H. papilio. A prima differt dormentia absenti (vs. dormentia praesenti), folia usque ad $92 \mathrm{~cm}$ longa (vs. usque ad $35 \mathrm{~cm}$ longa), floribus cum tepalis usque ad $5.1 \mathrm{~cm}$ longis (vs. usque ad $4.2 \mathrm{~cm}$ ), cum facie adaxiali candenti in parte centrali inferiori, et in parte superiori rubra, maculis linearibus divergentibus evidentibus coloris carminei qui nervaturas sequerunt a parte basali (vs. pars centro-inferioris rubra vel parva portione candenti, pars superioris rubra vel rubroaurantiacea, paucis maculis evidentibus coloris carminei qui nervaturas sequerunt solum in parte basali et in apice divergentes non fiunt, praesentia unae striae centro-longitudinalis coloris viridis) et lobis stigmaticis longis $1 \mathrm{~mm}$ circa, suberectis ad subpatentibus (vs. $4 \mathrm{~mm}$ patens-recurvati circa). A H. papilio differt quia stoloniferum (vs. propagatio ab gemmatione caulis), bulbo usque ad $9.7 \mathrm{~cm}$ diametri (vs. usque ad $12 \mathrm{~cm}$ diametri), perigonio leviter zygomorpho (vs. perigonium fortiter zygomorphum), tepalis facie adaxiali candenti in parte inferiori et rubra in parte superiori, maculis attenuatis coloris carminei qui sequerit nervaturas (vs. cremo-subvirides in omni extensione, maculis latis coloris carminei, qui dominans factus est in parte centrali tepalorum), lobis stigmaticis longis $1 \mathrm{~mm}$ circa, suberectis ad subpatentes (vs. $5 \mathrm{~mm}$ circa, patenterecurvati).

Type: BRAZIL. Santa Catarina: Treviso, saxícola em cachoeira, 30 January 2018, H.M.
Büneker 713 \& R.E. Bastian. (Holotype HDCF!).

Herb geophyte, saxicolous, stoloniferous, forming large agglomerations, $61-97 \mathrm{~cm}$ tall when flowering. Bulb globose 7.2-9.7 cm diam., covered by a few remnants of dead brown scabbards, then bare, white-greenish; pseudocolo absent up to $7 \mathrm{~cm}$. Leaves 4-9, always present, linear-oblanceolated, 31-92 $\times$ 3-4.7 cm, keeled at the basal portion, flattened at apex, ribbed with ca. 33 inconspicuous nerves and a prominent and conspicuous central nerve, abaxial face slightly pruinose, bright green, apex rounded, adaxial face glabrous, dark green. Inflorescence 2 flowered; scape cylindrical, hollow, 51-73 × 1.5-2.6 cm, compressed and whitish at the base, green on middle-upper portion, slightly pruinose; bracts 2, partially imbricated, free, partially dead and strongly reflexed during anthesis, oblanceolate, ca. 8.9$9.3 \times 1.7-3.1 \mathrm{~cm}$, whitish-brown and slightly hyaline at the base and central portion, becoming papiraceous, upper portion light green, apex obtuse-rounded; bracteoles 1 , triangular, ca. 8 $\times 0.5 \mathrm{~cm}$, papiraceous. Flower patent, pedicellate; pedicel trigonal at base and subcylindrical at upper portion, 3.2-4.3 $\times 0.5-$ $0.7 \mathrm{~cm}$, abaxially green and adaxially purple; hypanthium $0.5-0.7 \mathrm{~cm}$, externally green with scattered red macules and internally whitish; perigone infundibuliform, larger flowers up to $18 \mathrm{~cm}$ diameter; tepals subequal in shape, subpatent, slightly arched, up to $11.5 \mathrm{~cm}$ long, free above the hypanthium; abaxial face whitish at the base for one third of the length, the upper two thirds red, presenting a prominent greenreddish center longitudinal nerve in a form of line that reaches two-thirds of the length; adaxial face white-greenish at the base for one third of the length, the upper two thirds red, presenting a prominent whitish center longitudinal nerve in a form of line that reaches two-thirds of the length, in the transition region from white to red are observed small red macules on the white background until it turns completely red; the three upper perfectly equal in ornamentation of 

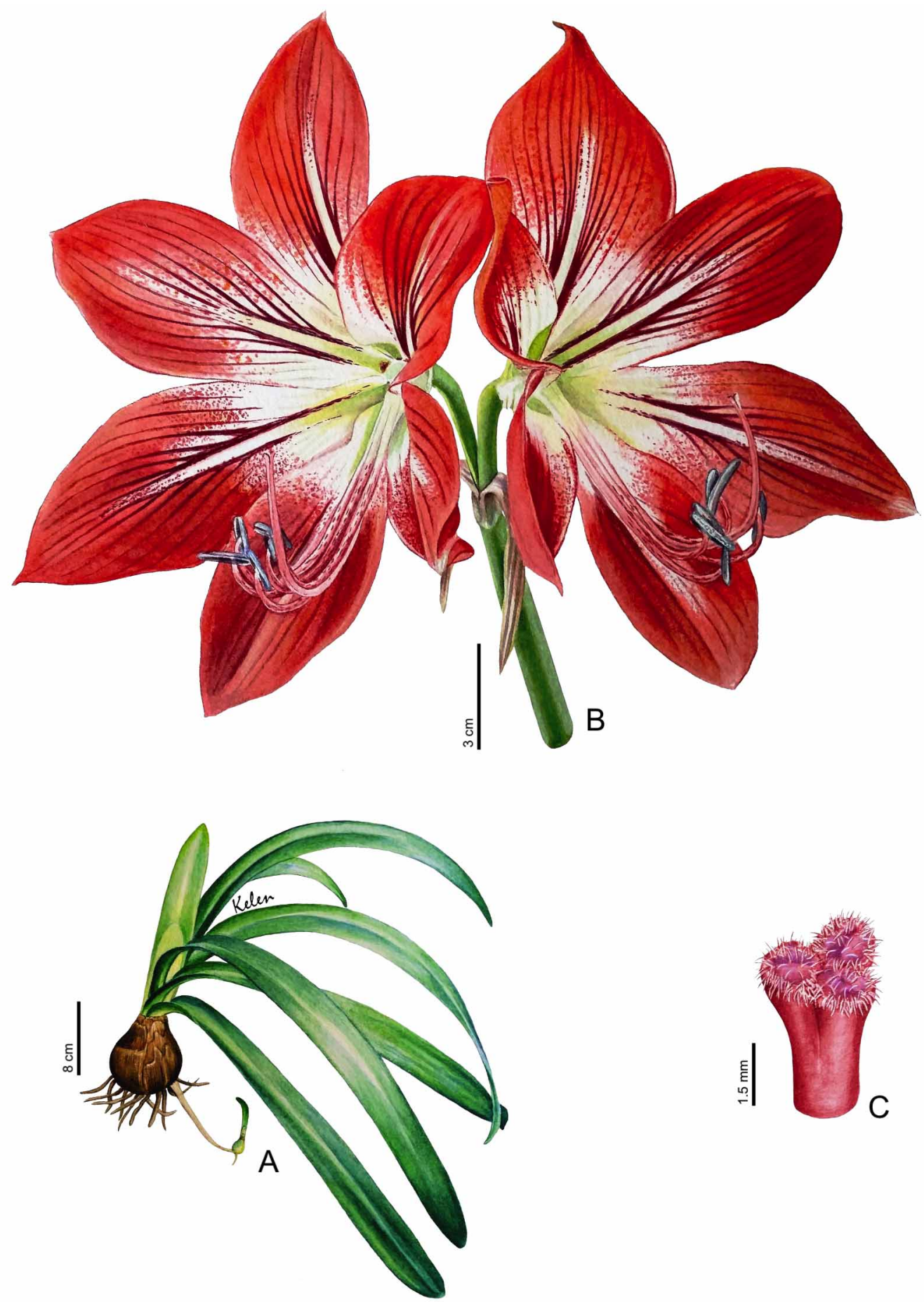

FIGURE 6 - Hippeastrum verdianum Büneker \& R. Bastian (Büneker 713 \& Bastian, Holotype). A - Vegetative habit. $\mathrm{B}$ - Detail of inflorescence. C - Detail of stigma. 

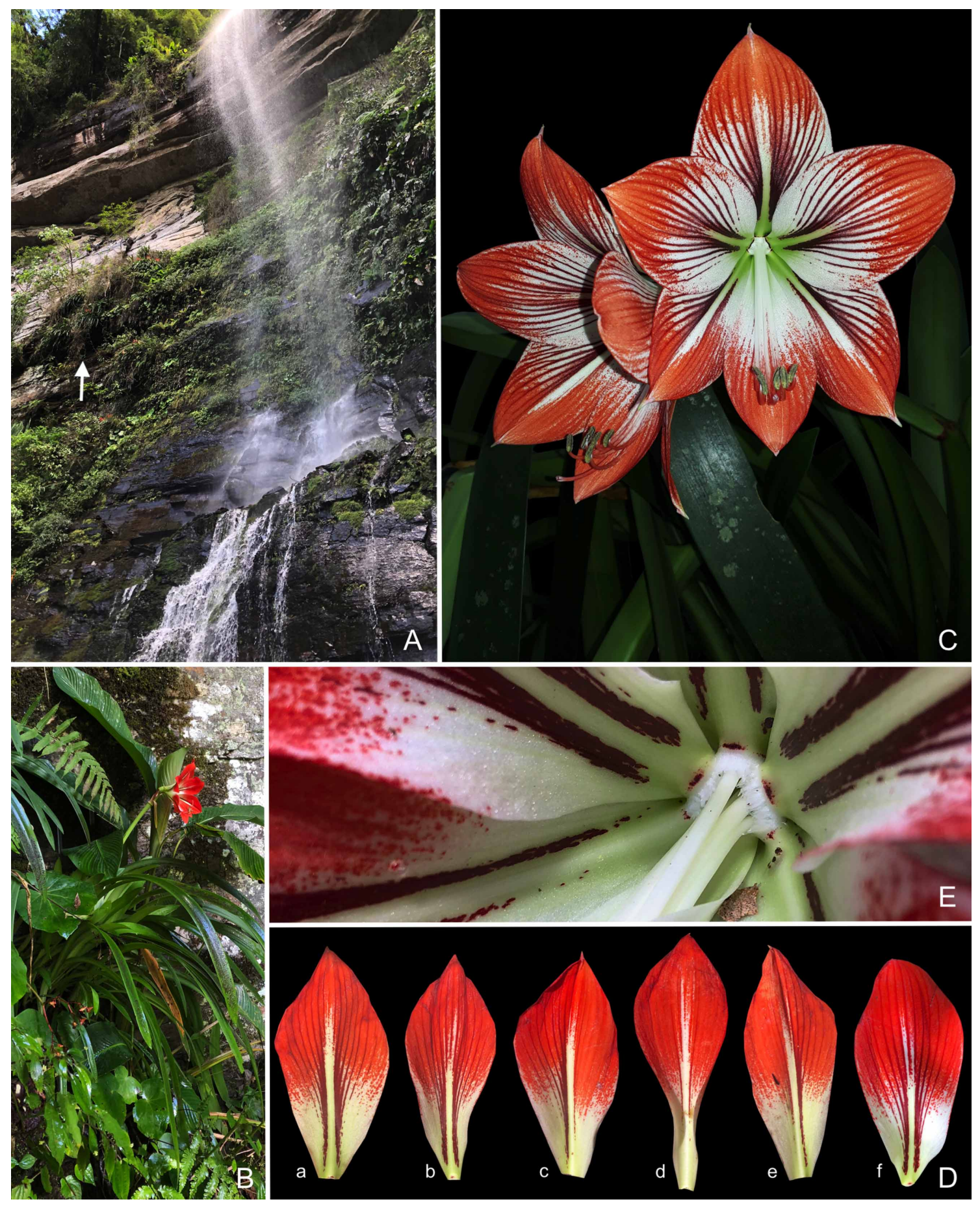

FIGURE 7 - Hippeastrum verdianum Büneker \& R. Bastian (B, E and D - Büneker 713 \& Bastian, Holotype; C - Bastian $138 \&$ Büneker, Paratype). A - Habitat on a rocky escarpment with waterfall, the arrow indicates the individuals. B - Habit during anthesis in habitat. C - Detail of inflorescence, plant in cultivation. D - Tepals of a flower dissected. $\mathrm{a}$ - upper tepal of the external whorl; $\mathrm{b}$ and $\mathrm{f}$ - upper tepals of the internal whorl; $\mathrm{c}$ and $\mathrm{e}$-inferior tepals of the external whorl; e - inferior tepal of the internal whorl. E - Detail of paraperigone. 
the nerves and individually perfectly zygomorphic; tepals of the external whorl, the upper one elliptic, $8.1-11 \times 3.9-5.1 \mathrm{~cm}$, presenting ca. 7 (on each side) perfectly bilaterally secondary nervures ornamented with magenta coloration, apex rounded-acuminate or apiculate, the lateral lower ones obovatedoblanceolated, 8.3-11.5 × 4.4-4.7 cm, asymmetrically ornamented, with one side with ca. 7 secondary nervures ornamented with magenta staining and other side with 1-3 nervures ornamented with magenta coloration, apex rounded-acuminate or apiculate; tepals of the internal whorl, lateral ones equal to the upper ones of the external whorl, however with apex obtuse, the lower one oblanceolated, 7.6-11.5 $\times 3.1-3.8 \mathrm{~cm}$, presenting 1-2 (on each side) perfectly bilaterally secondary nervures ornamented with magenta coloration, base with margins inflexed, partially embracing the cluster of filaments and stylus, apex roundedcuspidated; paraperigone in ring of partially connate or free fimbriaes, in its insertion to the tepals presenting macules with magenta coloration only in the center or all region of connection, fimbriaes white, 1.3-4 mm long; filaments declinate-ascending, white up to the middle region, with red macules that grow denser towards the apex until they cover the whole structure, slightly flattened, 1.6-2.47 mm diam., the longest 7.5-11 cm long, the shortest $6.9-9.8 \mathrm{~cm}$ long; anthers versatile, $0.5-2.3 \mathrm{~cm}$ long, purple; ovary trigonous, $1-1.5 \times 0.5-0.9$ $\mathrm{cm}$; ovules with axillary placentation, biseriate, subdiscoid; stylus declinate-ascending, 8.9-14.6 $\times$ ca. $0.2 \mathrm{~cm}$; stigma trifid; stigma lobes elliptic, suberect to subpatent at anthesis, 1.2-1.4 $\times$ ca. $1 \mathrm{~mm}$, red-pinkish surface.

Specimens examined (paratypes): BRAZIL. Santa Catarina: Treviso, Nova Brasília, 30 January 2010, M. Verdi 3503, D.M. Klettenberg \& G. Klems (FURB); terrestre em solo litólico no interior da mata, 30 January 2018, R.E. Bastian 138 \& H.M. Büneker (PACA); Bom Retiro, fazenda Campo dos Pa- dres, 25 January 1957, L.B. Smith \& R. Reitz 10457 (US 2248154 and 2248155).

Etymology: The specific epithet "verdianum" honors MS. Marcio Verdi (currently active at the National Center for Plant Conservation (CNCFlora) in Brazil), botanist and ecologist who located the species during the forest activities inventory of the state of Santa Catarina. The honoree promptly provided valuable information for us to locate a population of the species as well as personal observations about the plant.

Distribution, Habitat and Ecology: The species is known to only two populations, which we visited in the municipality of Treviso, in the state of Santa Catarina, Brazil. This population is saxicolous in a shaded environment with high relative air humidity, in waterfall's rocky escarpment, and in rocky surroundings. This population is immersed in the Atlantic rain forest in the lower part of the slope of the southeastern rim of the Brazilian southern plateau. Similar environments were observed in the vicinity of its population, however they are difficult to reach due to sloping terrain, and were not verified. We also located in a herbarium collection of the specimen for the region known as "campo dos padres", in the municipality of Bom Retiro. It is necessary to investigate the real extent of the occurrence of the species. In the vicinity of its populations, other species of Hippeastrum subgen. Omphalissa, $H$. glaucescens and $H$. cf. psittacinum can be observed in field heliophyte environment, and H. aulicum epiphyte.

Taxonomic observations: Hippeastrum verdianum is morphologically similar mainly to $H$. correiense, but also secondarily to $H$. papilio. It differs from $H$. correiense for not showing dormancy ( $v s$. presents dormancy), larger leaves (up to $92 \mathrm{~cm} v s$. up to $35 \mathrm{~cm}$ ), flowers with overall larger tepals (up to $5.1 \mathrm{~cm}$ vs. up to 4.2 $\mathrm{cm}$ ), with coloration and distinctive 
ornamentation in shape (green basal portion, lower white portion, red upper portion, with the presence of evident divergent linear maculae staining magenta, following the nerves of the basal portion $v s$. green basal portion, centralinferior portion red or with a small white portion, upper portion red or red-orange, with the little evident presence of coloration that accompany only the nerves in its basal portion, and do not become divergent at the apex, presence of a longitudinal green center stripe, and shorter stigmatic lobes with different position (ca. $1 \mathrm{~mm}$ suberect to subpatent $v s$. ca. $4 \mathrm{~mm}$ recurved patent). In a first analysis $H$. verdianum appears to differ significantly from $H$. papilio through the coloration of its tepals. However, its populations occupy the same type of environment and are geographically close. In an accurate analysis we can observe that their vegetative and behavior are alike, as well as the shape and size of the upper tepals. The new species can be differentiated from $H$. papilio, for being stoloniferous ( $v s$. present propagating by budding of the stem), small bulb (up to 9.7 $\mathrm{cm} v s$. up to $12 \mathrm{~cm}$ ), slightly zygomorphic perigone by the shape of the tepals ( $v s$. perigone strongly zygomorphic by the shape of tepals, upper tepals larger than lower ones), coloration and ornamentation (white in the lower part and red in the upper part, with narrow maculae magenta that accompany the nerves $v s$. pale green, with large maculae magenta that make this color dominant in the central part of the tepals), short stigmatic lobes an suberectsubpatent (ca. $1 \mathrm{~mm}$, suberect to subpatent $v s$. ca. $5 \mathrm{~mm}$, recurved patent). Eventually, the species can be confused in herbaria specimens with $H$. glaucescens, which also occurs in the vicinity of $H$. verdianum populations. However, it can be easily distinguished from $H$. glaucescens, which occurs in heliophyte environment, due to the presence of dormancy period, glaucous leaves, flowers with erect tepals, with shape and ornamentation of distinct coloration, and longer patent and recurved stigmatic lobes.

\section{ACKNOWLEDGMENTS}

The authors thank to André Gehlen, for his assistance with the living collection and field trip, to the professor of Latin, Leila Maraschin for her assistance with the translation of the diagnosis; Kelen Pureza Soares for elaborating the illustration of the new species; José Newton Cardoso Marchiori for the editation of this article; and for Manuel J. Belgrano of Instituto de Botánica Darwinion and James Shields for providing rare literature.

\section{REFERENCES}

BLOSSFELD, H. Notes on an Amaryllis species from Brazil. Plant Life, v. 35, p. 17-19, 1979.

BÜNEKER, H.M.; BASTIAN, R.E. Desambiguação taxonômico-nomenclatural e tipificação das espécies do grupo Sealyana (Amaryllidaceae, Amaryllidoideae), e seus sinônimos. Balduinia, n. 53, p. 15-30, 2016.

BÜNEKER, H.M.; BASTIAN, R.E. Taxonomic novelties in south brazilian Amaryllidaceae - I: Hippeastrum ramboi a new species from Rio Grande do Sul and lectotypification of $H$. breviflorum Herb. Balduinia, n. 60, p. 1-10, 2017.

BÜNEKER, H.M.; BASTIAN, R.E. Taxonomic novelties in southern brazilian Amaryllidaceae II Zephyranthes comunelloi, a new species from Santa Catarina; and lectotypification of Zephyranthes mesochloa Herb. ex Lindl. Balduinia, n. 62, p. 1-8, 2018.

BÜNEKER, H.M.; BASTIAN, R.E.; SOARES, K.P.; COSTA, C.M. The genus Tocantinia (Amaryllidaceae, Amaryllidoideae) and two new species from Brazil. Balduinia, n. 53, p. 1-14, 2016.

CARRIÈRE, E.A. Griffinia blumenavia. Revue Horticole, v. 39, p. 32-33, 1867.

FLORA DO BRASIL 2020 (autoria não atribuída). Amaryllidaceae. In: Flora do Brasil 2020 em construção. Jardim Botânico do Rio de Janeiro. Available from: http://floradobrasil.jbrj.gov.br/ reflora/floradobrasil/FB43 (accessed 4-IV2018).

FONTES, L.R.; HAGEN, S. Fritz, ou Frederico Müller, Notas sobre o sentido da brasilidade de Fritz Müller. In: Para Darwin (Für Darwin, 
1864 ) por Fritz Müller. Florianópolis: Editora da UFSC, p. 277-279, 2009.

HARMS, H.A.T. Bemerkenswerte seltenere pflanzen des Berliner Gartens, welche in denselben in letzter zeit aus ihrer heimat eingeführt wurden. Notizblatt des königl. Botanischen Gartens und Museums zu Berlin, n. 3, p. 81-84, 1895.

HERBERT, W. Amaryllidaceae. James Ridway \& Sons, London, 1837. 428 p.

HERBERT, W. An Appendix [Botanical Magazine]. James Ridgway, London, 1821. 52 p.

HERBERT, W. Habranthus gracilifolius. Slenderleved Habranthus. Botanical Magazine, v. 51, t. 2464, 1824.

HOOKER, W.J. Amaryllis aulica var. platypetala, glaucophylla. Glaucous-leaved, Broad-petaled Amaryllis. Curtis's botanical magazine, v. 57, t. 2983, 1830.

IUCN, Guidelines for Using the IUCN Red List Categories and Criteria. Version 12. IUCN, Gland, 2016, 101 p. Available from: http:// iucnredlist.org (accessed 4-IV-2018).

LINDLEY, J. Zephyranthes mesochloa. Half-green Zephyranthes. Edwards's botanical register, v. 16, t. 1361, 1830.

LINNAEUS, C. Species Plantarum, v. 1, 1753. 560 p.

MARCHIORI, J.N.C. Elementos de dendrologia, $3^{\mathrm{a}}$ Edição, Editora UFSM, Santa Maria, 2013. 216 p.

MEEROW, A.W.; VAN SCHEEPEN, J.; DUTILH, J.H.A. Transfers from Amaryllis to Hippeastrum (Amaryllidaceae). Taxon, v. 46, n. 1, p. 15-19, 1997.

PIRATELLI, A.J. Comportamento alimentar de beijaflores em duas espécies de Hippeastrum Herb. (Amaryllidaceae). Revista Brasileira de Biologia, v. 57, p. 261-273, 1997.

RAFINESQUE, C.S. Flora Telluriana, v. 4, 1838. $135 \mathrm{p}$.

RAVENNA, P.F. Contribuições ao estudos das Amaryllidaceae da América do Sul. Sellowia, n. 19, p. 25-36, 1967.
RAVENNA, P.F. Contributions to South American Amaryllidaceae III. Plant Life, v. 26, p. 73-103, 1970.

RAVENNA, P.F. Contributions to South American Amaryllidaceae VI. Plant Life, v. 30, p. 29-79, 1974.

RAVENNA, P.F. Contributions to South American Amaryllidaceae IX. Plant Life, v. 38, p. 452455, 1982.

RAVENNA, P.F. Eithea, a new genus of Brazilian Amaryllidaceae. Botanica Australis, v. 1, p. 18, 2002.

RAVENNA, P.F. New species of Zephyranthes and Habranthus (Amaryllidaceae) I. Onira, v. 3, n. 16, p. 52-61, 1999.

RAVENNA, P.F. New species of Zephyranthes and Habranthus (Amaryllidaceae) III. Onira, v. 6, n. 5, p. 38-40, 2001.

REITZ, R. O bromeliário ecológico do Jardim Botânico do Rio de Janeiro. Sellowia, n. 26, p. 68-75, 1975.

SMITH, S.F. Lyman Bradford Smith (1904-1997). Taxon, v. 46, n. 4, p. 819-824, 1997.

SWEET, R. Habranthus robustus, Robust Habranthus. The British Flower Garden, v. 4, pl. 14, 1838.

THIERS, B. Index Herbariorum: A global directory of public herbaria and associated staff. New York Botanical Gardens' Virtual Herbarium. Available from: http://sweetgun.nybg.org/ih/ (accessed 4IV-2018).

TRAUB, H. P. New Amaryllis species. Plant Life, v. 14, p. 30-32, 1958.

TURLAND, N.J.; WIERSEMA, J.H.; BARRIE, F.R.; GREUTER, W., HAWKSWORTH, D.L.; HERENDEEN, P.S.; KNAPP, S.; KUSBER, W.H.; LI, D.-Z.; MARHOLD, K.; MAY, T.W.; MCNEILL, J.; MONRO, A.M.; PRADO, J.; PRICE, M.J.; SMITH, G.F. (eds.). International Code of Nomenclature for algae, fungi, and plants (Shenzhen Code) adopted by the Nineteenth International Botanical Congress Shenzhen, China, July 2017. Regnum Vegetabile, v. 159, 2018. 